\title{
Comment on the article "The burden of avoidable disease from air pollution: implications for prevention"
}

\author{
Paweł Gać, Karolina Czerwińska \\ Department of Hygiene, Wroclaw Medical University, Poland
}

ADDRESS FOR CORRESPONDENCE: Paweł Gać, Department of Hygiene, Wroclaw Medical University, 7 J. Mikulicza-Radeckiego St., 50-345 Wrocław, Poland, e-mail: pawelgac@interia.pl

In their article, Samet and Buran indicate that the potential public health benefits of reducing the consumption of tobacco products may be greater than in the case of improving air quality [1]. However, the authors encourage prudent interpretation of the statistics and warn against creating artificial contest between tobacco control and air quality management. We consider this opinion to be correct, as both air pollution and exposure to tobacco smoke constitute significant threats to the health and life of Poles. It is ambiguous to clearly define which of these issues should be the priority of governmental control measures. The need for such prioritization also seems doubtful. We argue that both issues should be treated as equally important. Public authorities have a constitutional obligation to prevent various negative effects of environmental pollution on the health of inhabitants [2], no matter how large the potential gains are and whether these activities are profitable from the perspective of the government.

When compared to tobacco smoke, the problem of air pollution and its impact on the health of Poles has only become a part of important public debates in recent years. Although the disturbing scientific reports linking air pollution and premature mortality appeared many years ago [3], they did not lead to effective interventions to improve air quality. According to recent reports, among 100 cities with the most polluted air in Europe, as many as 29 are in Poland [4]. This situation may be the result of the fact that in the 20th century Poland lacked effective legal regulations concerning the emission of pollutants. Hope for improvement in air quality was raised by the launch of the National Air Protection Program in 2015 [5]. The main goal of this program is to improve air quality throughout Poland and, consequently, to reduce premature mortality related to air pollution. However, the programme has been in place since a relatively short time, and it is still difficult to assess its effectiveness. Undoubtedly, the path to clean air requires long-term and comprehensive actions.

According to statistics, individual heating of buildings is the greatest source of air pollutants in Poland [5]. Therefore, reducing household heating emissions is the most important measure from the perspective of improving air quality. Achieving this goal, however, will be difficult, because it requires not only coherent and realistic legal regulations, but also changes in the awareness and mentality of Poles. For many years there was a broad social acceptance of behaviours leading to air pollution. The condition of the heating system within the household, as well as the type of fuel used, were considered an individual matter of the owner, ignoring the fact that air is a common good for all citizens. This conviction was captured by the results of a study assessing the level of awareness and attitudes of Poles towards air quality [6]. When asked about the reasons for not taking action to reduce pollutant emissions, over $47 \%$ of respondents answered that the government or local government is responsible for taking appropriate action, and over $25 \%$ of respondents did not believe that individual actions can contribute to reduce pollutant emissions. It is also worth noting a certain difficulty in conducting educational activities regarding the harmfulness of air pollution, compared to, for example, education on the harmful effects of smoking. Quitting smoking is associated with a direct individual benefit of improved health. In the case of reducing pollutant emission, it is difficult 
to see immediate and direct benefits, which may result in weaker motivation to take action. Therefore, it is crucial to undertake both educational and motivational activities to build a sense of individual responsibility for the air quality.

Economic reasons are another difficulty in the fight for clean air. It is estimated that in 2016 around $12 \%$ of Poles, or over 4.6 million people, were affected by energy poverty [7]. The lack of sufficient funds to cover heating costs translates into the use of the cheapest fuels that do not meet the basic standards, as well as waste incineration. This issue is a great challenge for the government and requires the provision of a wide range of support instruments for energy poor households. The coming years will be key in terms of assessing the effectiveness of the measures taken so far to encourage residents to replace heat sources and improve the energy efficiency of single-family residential buildings. The recently introduced National Air Protection Program [5] is a major undertaking in this respect. However, a comprehensive evaluation of the programme's effectiveness will only be possible in the coming years.

\section{DISCLOSURE}

The authors report no conflict of interest.

\section{References}

1. Samet J, Buran M. The burden of avoidable disease from air pollution: implications for prevention. J Health Inequal 2020; 6 (1): 2-6.

2. Art. 74 Konstytucji Rzeczypospolitej Polskiej z dnia 2 kwietnia 1997 r. (Dz.U. nr 78, poz. 483) [Art. 74 of the Constitution of the Republic of Poland of April 2, 1997].

3. Bell ML, Davis DL, Fletcher T. A retrospective assessment of mortality from the London smog episode of 1952: the role of influenza and pollution. Environ Health Perspect 2004; 112 (1): 6-8.

4. IQAir ranking: World's most polluted cities. Available from: https://www.iqair.com/world-most-polluted-cities?continent= 59af92ac3e70001 $\mathrm{clbd} 78 \mathrm{e} 52 \&$ country $=\&$ state $=\&$ page $=1 \&$ per Page $=50 \&$ cities $=($ accessed: 11 December 2020 $)$.

5. Ministerstwo Środowiska, Departament Ochrony Powietrza. Krajowy Program Ochrony Powietrza do roku 2020 (z perspektywą do roku 2030) [National Air Protection Program until 2020 (with an outlook until 2030)]. Ministerstwo Środowiska, Warszawa 2015.

6. Jednotematyczne badanie świadomości i zachowań ekologicznych mieszkańców Polski. Jakość powietrza. Raport z badania 2019 [One-thematic study of ecological awareness and behaviours in Poland. Air quality. Research report 2019]. Available from: https:/www.gov.pl/web/klimat/badania-swiadomosci-ekologicznej (accessed: 11 December 2020).

7. Boguszewski R, Herudziński T. Ubóstwo energetyczne w Polsce [Energy poverty in Poland]. SGGW, Warszawa 2018.

\section{AUTHORS' CONTRIBUTIONS}

PG prepared concept and design of the article. PG and KC wrote the article and finally approved it. 